BIODIK: Jurnal IImiah Pendidikan Biologi
ISSN 2580-0922 (online), ISSN 2460-2612 (print)
Volume 6, Nomor 03, Tahun 2020, Hal. 232-241
Available online at:
https://online-journal.unja.ac.id/biodik

Research Article open Access

\title{
Beban Kognitif Siswa Pada Materi Pencemaran Lingkungan Berbantuan Prezi Application
}

\section{(Student Cognitive Load on Environmental Pollution Material Assisted by Prezi Application)}

Eka Lesmana Sari*, Billyardi Ramdhan, Sistiana Windyariani

Universitas Muhammadiyah Sukabumi

JI. R. Syamsudin, S.H. No. 50, Cikole, Kota Sukabumi, 43113, Indonesia

${ }^{*}$ Corresponding Auther: ekalemsna22@ummi.ac.id

\begin{tabular}{|c|c|}
\hline Informasi Artikel & ABSTRACT \\
\hline $\begin{array}{l}\text { Submit: } 01-07-2020 \\
\text { Diterima: } 07-08-2020 \\
\text { Dipublikasikan: } 01-09-2020\end{array}$ & $\begin{array}{l}\text { Cognitive load theory is a theory used to study the limitations of } \\
\text { working memory in receiving and processing new information } \\
\text { obtained by students, mental efforts owned by students and student } \\
\text { learning outcomes after studying the learning that has been } \\
\text { presented. The purpose of this study was to determine the cognitive } \\
\text { load profile of students of class VII Junior High School Sukabumi on } \\
\text { environmental pollution material with the help of prezi application. } \\
\text { Qualitative descriptive research method with research subjects as } \\
\text { many as } 40 \text { students. The instrument uses description questions, } \\
\text { questionnaires, and multiple choice questions. The results of the } \\
\text { study describe that the cognitive load profile of students' intellectual } \\
\text { cognitive load (ICL) in receiving and processing information has a } \\
\text { fairly high average value of } 81.25 \text {. This shows that the cognitive load } \\
\text { profile of students is low, then the results described from the } \\
\text { extraneous cognitive load (ECL) in the mental efforts of students get } \\
\text { an average value of } 65.2 \text {. This illustrates that there is a cognitive load } \\
\text { profile that is owned by students and finally the learning outcomes } \\
\text { using germane cognitive load (GCL), where students get an average } \\
\text { score of } 63 \text {, this is the same as ECL which describes students as } \\
\text { having a cognitive load profile because of the low value of learning } \\
\text { outcomes. obtained by students. } \\
\text { Keywords: Student Cognitive Load, Prezi Application }\end{array}$ \\
\hline Penerbit & ABSTRAK \\
\hline $\begin{array}{l}\text { Program Studi Pendidikan } \\
\text { Biologi, Fakultas Keguruan dan } \\
\text { IImu Pendidikan, Universitas } \\
\text { Jambi }\end{array}$ & $\begin{array}{l}\text { Teori beban kognitif merupakan teori yang digunakan untuk } \\
\text { mempelajari keterbatasan memori kerja dalam menerima dan } \\
\text { mengolah informasi baru yang diperoleh peserta didik, usaha mental } \\
\text { yang dimiliki oleh peserta didik dan hasil belajar peserta didik setelah } \\
\text { mempelajari pembelajaran yang sudah disampikan. Tujuan Penelitian } \\
\text { ini untuk mengetahui profil beban kognitif peserta didik kelas VII } \\
\text { Sekolah Menengah Pertama Negeri Kota Sukabumi pada materi } \\
\text { pencemaran lingkungan dengan berbantuan prezi application. Metode } \\
\text { penelitian deskriptif kualitatif dengan subyek penelitian sebanyak } 40 \\
\text { orang peserta didik. Instrumen menggunkan soal uraian, kuisioner, } \\
\text { dan soal pilihan ganda. Hasil penelitian mendeskripsikan bahwa profil } \\
\text { beban kognitif siswa instrisic cognitive load (ICL) dalam menerima } \\
\text { dan mengolah informasi memiliki nilai rata-rata yang cukup tinggi } \\
\text { yaitu } 81,25 \text {. Hal tersebut menunjukkan profil beban kognitif yang } \\
\text { dimiliki peserta didik rendah, kemudian hasil yang digambarkan dari } \\
\text { extraneous cognitive load (ECL) dalam usaha mental peserta didik } \\
\text { memperoleh nilai rata-trata } 65,2 \text {. Hal tersebut menggambarkan }\end{array}$ \\
\hline
\end{tabular}


terdapat profil beban kognitif yang dimiliki oleh siswa dan yang terakhir hasil belajar dengan menggunakan germane cognitive load (GCL) yaitu siswa memperoleh nilai rata-rata 63 hal tersebut sama dengan ECL yang menggambarkan peserta didik memiliki profil beban kognitif karena rendahnya nilai hasil belajar yang diperoleh peserta didik.

Katakunci: Beban kognitif siswa, aplikasi prezi

This BIODIK : Jurnal Ilmiah Pendidikan Biologi is licensed under a CC BY-NC-SA (Creative Commons Attribution-ShareAlike 4.0 International License)

\section{PENDAHULUAN}

Belajar merupakan proses mencari pengetahuan dan meningkatkan keterampilan yang berkaitan dengan pengetahuan yang dicari (Rusman, 2017). Dalam proses belajar, siswa berpusat pada kemampuan mental atau kognitifnya untuk dapat memahami pembelajaran yang dipelajarinya (Nursit, 2015). Di sekolah siswa banyak menerima informasi, terutama dari mata pelajaran yang bermacammacam yang harus dipahami dan dipelajari. Dalam pembelajaran IPA di sekolah banyak dijumpai siswa yang mengalami kesulitan dan kurang memahami pembelajaran. Hal ini disebabkan karena pembelajaran IPA berkenaan dengan pemahaman konsep dan penalaran (Ahmad, 2015).

Informasi yang diterima pada dasarnya tidak akan bisa disampaikan dalam jumlah yang banyak di dalam memori kerja. Hal ini dikarenakan kapasitas memori kerja sangat terbatas, yaitu hanya beberapa elemen saja yang dapat diterima (Sweller, 2010). Apabila informasi yang diterima terlalu banyak, maka akan membebani peserta didik dalam menerima informasi ketika proses pembelajaran., Beban yang diterima peserta didik dalam hal ini yaitu beban kognitif. Beban kognitif merupakan gambaran kognitif peserta didik yang berhubungan dengan memori kerja dalam pemprosesan informasi pada waktu tertentu. Penerimaan infromasi dan pemprosesannya berhubungan dengan memori jangka pendek dan memori jangka panjang (Nurwanda et al., 2020). Maka dari itu perlu strategi pembelajaran untuk dapat menyampaikan informasi secara baik dan benar kepada siswa (A Sadikin, 2018).

Menurut hasil wawancara saya dengan guru pamong di sekolah, ternyata peserta didik selain menerima informasi di sekolah yang diterima terlalu banyak pada saat pembelajaran, peserta didik juga memiliki masalah di luar sekolah sehingga pada saat peserta didik belajar di sekolah tidak bisa mengikuti pembelajaran sepenuhnya dengan baik. Hal tersebut dapat menambah beban yang dimiliki oleh peserta didik salah satunya terhadap profil beban kognitif yang dapat didefinisikan sebagai beban ketika melakukan tugas tertentu yang memaksa sistem kognitif siswa bekerja lebih keras (Moreno et al., 2010). Mental siswa perlu difokuskan sebelum pembelajaran dilaksanakan (Ali Sadikin et al., 2013). 
Untuk mengetahui profil beban kognitif yang dimiliki oleh peserta didik pada saat pembelajaran di sekolah dan pada saat mengalami permasalahan di luar sekolah, maka diadakankan tiga sumber profil beban kognitif untuk menggambarkan profil beban kognitif siswa di sekolah dengan menggunakan: 1) Intrinsic Cognitive Load; 2) Extraneous Cognitive Load; dan 3) Germane Cognitive Load (Sweller, 2010).

Berdasarkan tiga komponen profil beban kognitif di atas, untuk mengtahui profil beban kognitif siswa pada saat pembelajaran di sekolah dan masalah di luar sekolah maka dapat di gambarkan dengan memberikan tes soal uraian, kuisioner dan pilihan ganda. Keberadaan beban kognitif intrinsic, extraneous dan germane dapat ditelusuri dengan melakukan pengukuran untuk menggambarkan profil beban kognitif peserta didik dalam menerima dan mengolah informasi, usaha mental dan hasil belajar yang tersaji dalam materi ajar (Rahmat \& Hindriana, 2014).

Selain itu ada kecenderungan pendidik dalam menentukan strategi pembelajaran yang kurang menarik dan kurang interaktif, akan berakibat pada keberlangsungan proses pembelajaran (Zemmy, 2013). Akibatnya peserta didik akan melakukan usaha lain untuk memperoleh informasi tambahan di luar proses pembelajaran yaitu dengan cara mencari pada literatur bacaan. Hal tersebut dilakukan karena peserta didik merasa informasi yang di terima pada saat pembelajaran kurang cukup, sehingga peserta didik akan menacari cara untuk melengkapi informasi yang diterima pada saat pembelajaran. Strategi pembelajaran yang baik, apabila mampu mengelola usaha mental dan kemampuan menerima dan mengolah informasi peserta didik tinggi (Paas et al., 2003). Beban kognitif Extraneous dapat ditelusuri dengan pengukuran diluar poses pembelajaran (Rahmat \& Hindriana, 2014).

Beban kognitif selanjutnya yaitu beban kognitif Germane. Beban kognitif Germane ini merupakan beban yang penting dalam proses belajar. Beban ini disebut sebagai beban dalam mengkontruksi skema kognitif dan bisa muncul karena ICL atau ECL (Sweller, 1994). Oleh karenanya, supaya tercapainya pembelajaran yang efektif yaitu melalui mengelola beban kognitif instrinsic dan mengurangi beban kognitif extraneous sehingga akan meningkkatkan beban kognitif germane (Kalyuga, 2011).

Jadi salah satu alternatif strategi pembelajaran pada proses belajar mengajar di kelas tentunya tidak lepas dari pendekatan, metode dan strategi yang digunakan oleh pendidik. Apabila pendekatan, metode dan strategi pembelajaran yang digunakan tidak membantu menyampaikan informasi, maka kemampuan peserta didik untuk berpikir menjadi kurang terlatih dan kemampuan daya nalar peserta didik akan menjadi berkurang. Hal tersebut disebabkan karena pada saat pembelajaran, peserta didik tidak dibiasakan berpikir nalar, mereka hanya bisa meindahkan kalimatkalimat dari buku teks kedalam kertas kosong (Siwa \& Muderawan, 2013). Oleh karena itu pendekatan, metode dan strategi pembelajaran sangat berperan penting dalam proses pembelajaran terutama dalam membantu menyampaikan informasi. 
Saat ini penggunaan media pembelajaran lebih mengaruh pada media berbasis e-learning. Salah satu media berbasis e-learning adalah media prezi yang memiliki kelebihan dapat menampung gaya belajar. Media prezi ini program yang dapat menampilkan media visual, audio maupun animasi. Program prezi application ini merupakan media unik di dalamnya terdapat bentuk presentasi yang sangat berbeda dengan presentasi pada umumnya. Media prezi ini fokus pada satu bidang slide yang disebut dengan kanvas virtual. Selain itu pengguna dapat mengeksplorasi bagaian-bagian kanvas tersebut sehingga menjadi biagian-bagian terkecil, sehingga konsep utama yang ingin disampaikannya jelas.

Penggunaan fasilitas Zooming User Interface (ZUI) membuat presentasi terlihat dinamis karena kanvas dapat diperkecil, di perbesar bahkan diputar $360^{\circ}$. Selain itu prezi application ini merupakan aplikasi yang berbasis adobe air, sehingga video maupun animasi flash dapat dijalankan lebih ringan dari pada powerpoint, pada awalnya aplikais ini hanya dapat digunakan secara online, namun saat ini penggunaan prezi application dapat digunakan secara offline dengan dilincurkannya prezi desktop (Arifiya \& Hartini, 2020; Harahap, 2019; Rohiman \& Anggoro, 2019). Diperlukan media on line yang tepat untuk memudahkan siswa dalam belajar sesuai dengan kebutuhannya (Ali Sadikin \& Hakim, 2019). Penggunaan Media berbasis Prezi dapat meningkatkan hasil belajar siswa (Dewi \& Latifah, 2016). Berdasarkan latar belakang yang telah dikemukakan, maka penelitian ini bertujuan untuk mendeskripsikan gambaran profil beban kognitif siswa pada pelajaran IPA materi pencemaran lingkungan pada siswa SMPN 06 kelas VII Kota Sukabumi.

\section{METODE PENELITIAN}

Metode yang digunakan pada penelitian ini deskiptif kualitatif untuk mengetahui gambaran profil beban kognitif siswa kelas VII sekolah menengah pertama Negeri Kota Sukabumi pada materi pencemaran lingkungan. Subjek yang digunakan dalam penelitian ini adalah siswa dan siswi SMPN 06 Kota Sukabumi sebanyak 40 orang, dilakukan selama 1 kali pertemuan di kelas VII A 20 orang dan di Kelas VII B 20 orang. Penelitain ini dilakukan pada kelas VII A dan VII B karena kelas VII A memiliki nilai indeks yang baik sedangkan pada kelas VII B belum termasuk kriteria indeks yang kurang mencukupi. Tahap pembelajaran materi yang disampaikan berbantuan aplikasi prezi. Pada saat pertemuan pembelajaran dilakukan pengujian soal beban kognitif intrinsic, extraneous dan germane.

Pada tahap awal ini dilakukan pembelajaran secara daring tidak dilakukan pembelajaran secara bertatap muka, peneliti membuat perencanaan pelaksanaan pembelajaran dan menjelaskan materi yang akan di sampaikan melalui prezi application yang ditayangkan oleh peneliti. Lalu peneliti memberikan soal pilihan ganda, kuisioner dan soal uraian kepada peserta didik untuk mengumpulkan data dari hasil soal pilihan ganda, kuisioner dan soal tes uraian. Ketika semua data yang sudah terkumpul maka akan dideskripsikan oleh peneliti. 
Adapun prosedur pengumpulan data yang dilakukan dalam penelitian ini sebagai berikut:

1. Soal pilihan ganda

GCL (Germane Cognitive Load) diukur melalui soal pilihan ganda sebanyak 25 butir soal yang sifatnya untuk mengetahui hasil belajar siswa setelah melakukan pembelajaran pada materi pencemaran lingkungan dengan menggunakan kisi-kisi soal yang dikembangkan oleh (Marzano et al., 1993).

2. Kuisioner

ECL (Extraneous Cognitive Load) diukur melalui kuisioner ini digunakan untuk memperoleh usaha mental yang diperoleh dari peserta didik dengan pembelajaran berbantuan aplikasi prezi. Dalam hal ini menggunakan skala likert, untuk mengelompokkan siswa ke dalam empat ketegori yaitu kategori: sangat setuju, setuju, tidak setuju dan sangat tidak setuju (Moreno et al., 2010).

\section{Tes soal uraian}

ICL (Intrinsic Cognitive Load) ini diukur melalui instrumen test berupa soal uraian dengan kompleksitas isi soal yang berbeda (task complexity; Brunken dkk., 2010). Test soal uaraian tersebut merupakan tes soal yang dilakukan setelah pembelajaran selesai untuk mengukur penguasaan konsep siswa setelah menerima dan pengolah informasi dari hasil belajar, dengan diberikan soal uraian sebanyak 16 soal urain yang diberikan kepada peserta didik. Instrumen ini dikembangkan oleh (Marzano et al., 1993).

\section{HASIL DAN PEMBAHASAN}

Pada penelitian ini jawaban nilai yang diperoleh setelah mempelajaran siswa pada soal yang sudah dibuat dengan indikator yang dikembangkan oleh Marzano, menggunakan instrumen profil beban kognitif yang menggambarkan kemampuan menerima dan mengolah informasi ICL dengan menggunakan soal uraian, usaha mental ECL dengan menggunakan kuisioner, dan hasil belajar GCL dengan menggunakan soal pilihan ganda. Terdapat hasil yang telah diperoleh setelah pembelajaran selesai peserta didik yang diberikan soal uraian mendapatkan nilai rata-rata 81,25 , kuisioner untuk menggambarkan pembelajaran menggunakan berbantuan prezi application mendapatkan nilai rata-rata 65,2 dan soal pilihan ganda mendapatkan nilai rata-rata 63. dari kuisioner pembelajaran menggunakan prezi application diperoleh sebesar 65,2. Kemudian hasil belajar diperoleh sebesar 63 . Sesuai dengan teori beban kognitif terdapat Tiga komponen yang saling berhubungan yaitu (1) beban kognitif intrinsic (ICL), (2) beban kognitif exstraenous (ECL) dan (3) beban kognitif Germane (GCL). 


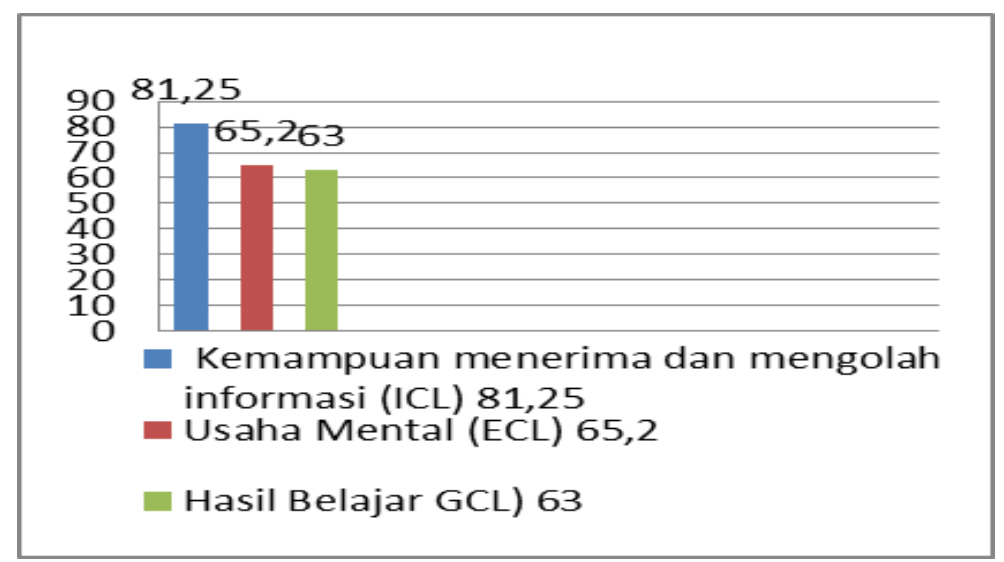

Gambar 1. Nilai Rerata Kognitif Siswa

Berdasarkan hasil yang digambarkan pada ICL di atas berbanding terbalik dengan hasil yang didapat dari ECL yang menunjukkan bahwa usaha mental yang di miliki oleh peserta didik rendah. Rendahnya ECL pada penelitian ini karena strategi pembelajaran yang berbantuan prezi application tersebut kurang di minati oleh peserta didik karena mereka kesulitan untuk memahami pembelajaran dengan menggunakan prezi application jika dijlaskan secara online. Berdasarkan pernyataan ini, maka pembelajaran online dengan menggunakan berbatuan prezi application ini menghasilkan ICL yang berada pada kapasitas memori kerjanya dengan ECL yang rendah (Çıbık, 2009). Suatu pembelajaran yang baik akan menghasilkan besarnya usaha mental yang berbanding terbalik dengan besarnya kemampuan menerima dan mengolah informasi (Sweller, 1994).

Selanjutnya pada GCL peserta didik mendapatkan nilai yang cukup tinggi walaupun masih berada pada standar minimal ketuntasan hasil belajar. Tingginya GCL disini dapat menunjukkan bahwa beban yang dihasilkan merupakan beban yang di kontruksi skema kognitif (Moreno, 2006). Yang dimaksud dengan skema kognitif disini yaitu berisi informasi yang saling berhubungan dan yang tersimpan lama di dalam memori kerja peserta didik. Pada penelitian ini tentunya informasi yang diterima mengenai materi yang disampaikan melalui prezi application sedikit diterima dan peserta didik mulai memahaminya materi yang di sampaikan di aplikasi prezi tersubut.

Pengukuran profil beban kognitif siswa tentunya bukan hanya dilihat dari tinggi rendahnya setiap komponen beban kognitif yang dicapai peserta didik, akan tetapi harus dilihat juga dari hubungan antara beban kognitif, berdasarkan hasil nilai yang didapat dari usaha mental (ECL) terhadap menerima dan mengolah informasi (ICL), menunjukkan hubungan yang negatif atau rendah. Hal tersebut sejalan dengan adanya profil beban kognitif, bahwa ECL memiliki pengeruh terhadap ICL. Jika kemampuan menerima dan mengolah informasi peserta didik mencapai tinggi maka usaha mentalnya akan rendah, ataupun sebaliknya jika ICL rendah maka ECL akan kurang, berarti dalam menerima informasi (Sweller, 1994). Sehingga hasil dalam penelitian ini menggambarkan bahwa penuruan usaha mental dapat memacu pada

\section{Eka Lesmana Sari. Dkk}


peningkatan kemampuan menerima dan mengolah informasi. Dalam hal ini peserta didik harus diberikan motivasi bahwa butuh kemandirian dalam hal mengerjkan tugas-tugas pembelajaran yang sudah diberikan (Santyasa, 2006).

Pada pemaparan di atas terdapat hasil positif antara kemampuan menerima dan mengolah informasi ICL terhadap hasil belajar GCL yang menunjukkan bahwa besarnya hasil belajar yang diperoleh oleh peserta didik dari hasil mengolah informasi pada saat pembelajaran, karena beban kognitif germane ini merupakan hasil dari pemahaman informasi dalam skema kognitif. Tentunya hal tersebut menunjukkan kesesuaian dengan teori beban kognitif bahwa strategi pembelajaran yang dikembangkan harus mempertimbangkan struktur informasi atau muatan kognitifnya. Hal ini bertujuan supaya peserta didik mampu menerima informasi sesuai kapasitas memori kerjanya (Paas et al., 2003). Walaupun demikian kontribusi kemampuan menerima dan mengolah informasi terhadap hasil belajar masih belum jelas karena tidak memiliki hubungan yang signifikan, sehingga memingkinkan peserta didik masih memiliki beban kognitif sekalipun sangat rendah. Hal ini dimungkinkan ada aspek lain yang berperan.

Hasil usaha mental ICL terhadap hasil belajar GCL pada kelas penelitian ini berada pada hubungan yang positif karena masih ada nilai yang mendakan masih ada sedikit usaha mental untuk mempeoleh hasil belajar. Hubungan positif ECL dengan GCL ini, menjadi jawaban anatara kemampuan menerima dan mengolah informasi (ICL) terhadap hasil belajar (GCL) tidak berhubungan secara signifikan. Hal ini dikarenakan masih adanya sedikit usaha mental yang dimiliki oleh peserta didik untuk memperoleh hasil belajar pada saat proses pembelajaran terdapat faktor yang dapat mempengaruhi strategi pembelajaran dan sumber belajar yang digunakan oleh pengejar.

Berdasarkan hasil penelitian di atas, tampaknya nilai yang sudah didapatkan dari hasil yang diperoleh dari ICL, ECL dan GCL terdapat nilai yang kurang memenuhi syarat KKM yang ditentukan oleh sekolah yaitu dengan nilai KKM 75 . Pada beban kognitif ICL kemampuan menerima dan mengolah informasi siswa mendapatkan nilai rata-rata 81,25 hal tersebut sudah memenuhi syarat KKM dan dapat menggambarkan beban kognitif siswa berkurang karena hasil dari menerima dan mengolah informasinya cukup tinggi, sedangkan pada ECL siswa mendapatkan nilai rata-rata 65,5 nilai tersebut belum memenuhi syarat KKM karena masih kurang dan dapat menggambarkan usaha mental yang dimiliki peserta didik masih kurang sehingga beban kognitif yang dimiliki oleh peserta didik masih tinggi dan yang terakhir pada GCL peserta didik memperoleh nilai rata-rata 63 hal tersebut menggambarkan nilai yang masih kurang untuk syarat KKM dan dapat menggambarkan hasil belajar siswa sangat rendah atau kurang sehingga beban kognitif yang dimiliki oleh peserta didik masih tinggi. 


\section{KESIMPULAN}

Berdasarkan nilai hasil yang menggambarkan ICL kemampuan menerima dan mengolah informasi mendapatkan nilai rata-rata 81,25 , untuk menggambarkan ECL usaha mantal diperoleh nilai rata-rata 65,2 , dan untuk menggambarkan nilai hasil belajar diperoleh nilai rata-rata 63 , setelah diketahui nilai yang menggambarkan profil beban kognitif, bisa dijadikan acuan untuk penelitian lanjutan bagi guru menurunkan beban kognitif pada peserta didik pada saat pembelajaran atau pada saat di luar pembelajaran karena seperti yang sudah dipaparkan di atas peserta didik tidak hanya memiliki beban kognitif pada saat proses pembelajaran akan tetapi di luar pembelajaran pun peserta didik masih memiliki beban yang membebani dirinya, hal tersebut bisa digunakan oleh guru untuk mencari informasi dan mencari alternatif, sehingga pada saat proses pembelajaran guru dapat menurunkan beban kognitif yang dimiliki oleh peserta didik.

\section{DAFTAR PUSTAKA}

Ahmad, N. Q. (2015). Pengaruh Pendekatan Pembelajaran dan Belief tentang IPA Terhadap Kemampuan Penalaran IPA. Jurnal Pencerahan, 9(1).

Arifiya, N., \& Hartini, S. (2020). Pemanfaatan Aplikasi Prezi di Lembaga Bimbingan Belajar Gama UI Cabang Duren Tiga Jakarta Selatan. Abdimas Siliwangi, 3(2), 238-244. https://doi.org/http://dx.doi.org/10.22460/as.v3i2p\%25p.3754

Çıbık, A. S. (2009). The effect of the project based learning approach to the attitudes of students towards science lesson. Elementary Education Online, 8(1).

Dewi, K. P., \& Latifah, L. (2016). Efektivitas Metode Problem Posing Berbantuan Media Prezi Untuk Meningkatkan Hasil Belajar Siswa Materi Jurnal Penyesuaian. Economic Education Analysis Journal, 5(1). https://doi.org/https://journal.unnes.ac.id/sju/index.php/eeaj/article/view/9985

Harahap, N. M. (2019). Pengaruh Model PBL Berbantuan Media Prezi dan Motivasi Terhadap Hasil Belajar Siswa Pada Materi Koloid. UNIMED.

Kalyuga, S. (2011). Informing: A Cognitive Load Perspective. Informing Sci. Int. J. an Emerg. Transdiscipl., 14, 33-45.

Marzano, R. J., Pickering, D., \& McTighe, J. (1993). Assessing Student Outcomes: Performance Assessment Using the Dimensions of Learning Model. ERIC.

Moreno, R. (2006). When worked examples don't work: Is cognitive load theory at an impasse? Learning and Instruction, 16(2), 170-181.

Moreno, R., Park, B., Plass, J. L., \& Brünken, R. (2010). Cognitive load theory. In Historical Development and Relation to Other Theories, Dalam. Cognitive load theory. Cambridge: Cambridge University Press.

Nursit, I. (2015). Pembelajaran Matematika Menggunakan Metode Discovery Berdasarkan Teori Beban Kognitif. Jurnal Pendidikan Matematika (JPM), 1(1), 42-52.

Nurwanda, Y., Milama, B., \& Yunita, L. (2020). Beban Kognitif Siswa Pada Pembelajaran Kimia di Pondok Pesantren. Jurnal Inovasi Pendidikan Kimia, 14(2), 2629-2641.

Paas, F., Tuovinen, J. E., Tabbers, H., \& Van Gerven, P. W. M. (2003). Cognitive load measurement as a means to advance cognitive load theory. Educational Psychologist, 38(1), 63-71. 
Rahmat, A., \& Hindriana, A. F. (2014). Beban kognitif mahasiswa dalam pembelajaran fungsi terintegrasi struktur tumbuhan berbasis dimensi belajar. Jurnal IImu Pendidikan, 20(1).

Rohiman, R., \& Anggoro, B. S. (2019). Penggunaan Prezi untuk Media Pembelajaran Matematika Materi Fungsi. Desimal: Jurnal Matematika, 2(1), 23-32. https://doi.org/https://doi.org/10.24042/djm.v2i1.3312

Rusman, R. (2017). Belajar dan Pembelajaran Berorientasi Standar Proses Pendidikan. In Jakarta: Kencana Prenada.

Sadikin, A. (2018). Penerapan jurnal belajar untuk meningkatkan motivasi belajar mahasiswa pada mata kuliah Dasar-Dasar dan Proses Pembelajaran Biologi. Bioeducation Journal, 2(1), 70-75.

Sadikin, Ali, \& Hakim, N. (2019). Pengembangan Media E-Learning Interaktif Dalam Menyongsong Revolusi Industri 4.0 Pada Materi Ekosistem Untuk Siswa SMA. BIODIK, 5(2), 131-138. https://doi.org/https://doi.org/10.22437/bio.v5i2.7590

Sadikin, Ali, Kamid, K., \& Hariyadi, B. (2013). Profil Berpikir Kritis Mahasiswa Tipe Phlegmatis dalam Pemecahan Masalah Biologi. Edu-Sains: Jurnal Pendidikan Matematika Dan IImu Pengetahuan Alam, 2(2). https://doi.org/https://doi.org/10.22437/jmpmipa.v2i2.1670

Santyasa, I. W. (2006). Pembelajaran inovatif: Model kolaboratif, basis proyek, dan orientasi NOS. Semarapura: Makalah.

Siwa, I. B., \& Muderawan, I. W. (2013). Pengaruh pembelajaran Berbasis Proyek dalam Pembelajaran Kimia terhadap Keterampilan Proses Sains ditinjau dari gaya kognitif siswa. Jurnal Pendidikan Dan Pembelajaran IPA Indonesia, 3(2).

Sweller, J. (1994). Cognitive load theory, learning difficulty, and instructional design. Learning and Instruction, 4(4), 295-312.

Sweller, J. (2010). Cognitive load theory: Recent theoretical advances. Cambridge University Press.

Zemmy, I. K. D. (2013). Upaya meningkatkan berfikir kreatif melalui pembelajaran kooperatif tipe tai berdasarkan teori beban kognitif. "CAKRAWALA PENDIDIKAN" Published by" STKIP PGRI BLITAR", 15(2), 243-250. 